\title{
The spectrum of accidental childhood poisoning in the Caribbean
}

\author{
Thomas C. Martin ${ }^{1}$ and William Brinkman ${ }^{2}$
}

ABSTRACT Objective. To assess accidental poisoning in children in the Caribbean country of Antigua and Barbuda, including the incidence, the types of substances ingested, the age of the children involved, and the clinical outcomes. The results from Antigua and Barbuda were compared with the results of other reports from the English-speaking Caribbean and from the United States of America.

Design and Methods. We performed a retrospective review of the charts of all patients less than 13 years old admitted to the Children's Ward at Holberton Hospital in Antigua for accidental poisoning between March 1989 and March 1999. Those data were compared with data from earlier reports from Barbados, Guyana, Jamaica, and the United States of America.

Results. In Antigua and Barbuda there were 255 hospital admissions for accidental poisoning among children below 13 years old over that 10-year period. Of the 255 ingestions, 115 of them $(45 \%)$ were in 1-year-old children, $69(27 \%)$ were in 2-year-old children, and $26(10 \%)$ were in 3-year-old children. These proportions in Antigua and Barbuda are similar to the age patterns seen in the other countries with which we made comparisons. In Antigua and Barbuda there was an annual average of 26 hospital admissions for poisoning for the roughly 20000 children below 13 years of age, for a rate of 1.3 per 1 000. In comparing the patterns of childhood poisoning in all the countries we studied, we found that, as economic levels rose, there was a shift in the substances ingested, with hydrocarbon and plant ingestions decreasing and chemical and medication ingestions increasing.

Conclusions. There is an increasing variety and complexity of poisonous substances ingested as economic conditions improve. This trend would make the establishment of a poison control center for the English-speaking Caribbean a logical step.

Key words Poisoning, child, infant, accidents, Caribbean.

Childhood poisoning due to ingestion is a significant problem in developed countries as well as in the English-speaking Caribbean (1-3). In the United States of America in 1990 there

\footnotetext{
1 Holberton Hospital, Paediatric Service, St. John's, Antigua and Barbuda; University of Rochester School of Medicine, Rochester, New York, United States of America. Send correspondence to: Thomas C. Martin, P.O. Box W879, Woods Centre, Antigua, West Indies; telephone: 268-462-1975; fax: 268-460-5258; e-mail: martint@candw.ag

2 Children's Memorial Hospital, Chicago, Illinois, United States; Northwestern University School of Medicine, Chicago, Illinois, United States.
}

were 1.7 million exposures (1). In the United States and Europe in 19841986, accidental poisoning accounted for about 0.5 deaths per 100000 population in children 1 to 4 years old (4). In 1992 in the United States, $90 \%$ of poisonings were in children less than 3 years old (5). The Caribbean has a similar age distribution for poisonings in children $(2,3,6)$.

This study was undertaken to assess poisonings among children in the Caribbean country of Antigua and
Barbuda, including the incidence, types of substances ingested, age of victims, and outcomes. The findings were compared with prior reports from the English-speaking Caribbean and from the United States of America $(2,3,5,6)$.

\section{METHODS}

We retrospectively reviewed admissions records from the Children's 
Ward of Holberton Hospital in St. John's, Antigua. Records from March 1989 to March 1999 were examined. Holberton Hospital is the only acute care facility for children in Antigua and Barbuda. The population of Antigua and Barbuda is about 65000 , with some $98 \%$ of the population living on the island of Antigua. The country's mean gross domestic product (GDP) per capita was US\$ 5377 in 1995 , with $65 \%$ of that coming from tourism. The population of children 04 years old in Antigua and Barbuda was estimated to be 6152 in 1991 and 6670 in 1995. The number of children below 13 years old was about 20000 during the years of the study.

Using the admission records, we recorded the ages of the children, the types of ingested substances, and the deaths. We compared these results with results of prior reports from Barbados (6), Guyana (3), Jamaica (2), and the United States (5). (While Guyana is actually located in South America, it is often considered a part of the Englishspeaking Caribbean for research on health and other issues.) In ascending order, the mean GDP per capita for those four countries was: Guyana, US\$ 995 in 1988; Jamaica, US\$ 2079 in 1977; Barbados, US\$ 3700 in 1978; and the United States, US\$ 18448 in 1987 (7). (All those GDP figures are standardized in 1978 United States dollars; the year indicated for each country is matched to the year of the data from each of the respective reports $(2,3,5$, 6)). A meta-analysis was not possible due to the variety of medical settings and the lack of uniformity in data accrual. Therefore, we only performed a qualitative comparison of the data.

\section{RESULTS}

In the 10-year period reviewed in Antigua and Barbuda, 255 children less than 13 years old were admitted to Holberton Hospital for treatment for poisoning. Poisoning was most likely in 1-year-old children, accounting for $45 \%$ of ingestions. Next in frequency were 2-year-old children $(27 \%)$, and then 3-year-old children $(10 \%)$. Infants less than 1 year old accounted for $5 \%$ of cases. The remaining $13 \%$ of children ranged in age from 4 to 12 years. More boys $(57 \%)$ than girls were admitted. Children with a history of possible accidental poisoning were admitted regardless of symptoms. None of the ingestions in this age group was felt to be non-accidental (i.e., child abuse) or intentional (i.e., a suicide gesture).

The most frequently ingested substance was chemical (bleach, caustic, pesticide, rat poison, etc.), 90 of 255 ingestions, or $39.5 \%$ (Table 1). Bleach (termed as "Clorox," for the brand name) accounted for $56 \%$ of the chemical ingestions.

Medications accounted for 66 of 255 ingestions, or $26 \%$. Heading the category were unidentified tablets (18 cases), followed by salves of various types ( 6 cases) and oral contraceptives (5 cases). Hydrocarbon ingestions accounted for 61 of 255 cases, or $24 \%$, with kerosene accounting for 39 cases (64\% of the hydrocarbon ingestions). Plants accounted for 3\% of ingestions. Various other substances, including mercury (3 cases), hydrogen peroxide ( 2 cases), glue (1 case), and 21 unknown substances accounted for $12 \%$ of the ingestions. There was one fatality, an 11-month-old who ingested kerosene during a period in 1998 after Hurricane Georges had struck Antigua and Barbuda and many households had lost electricity.

Table 2 lists data on reported ingestions from Guyana in 1992 (3), Jamaica in 1977 (2), Barbados in 1975-1980, (6), Antigua in 1989-1999, and the United States in 1990 (5). Ingestions were separated into chemical, medication, hydrocarbon, plant, or "other." The type of poisoning as a percent of total ingestions suggests a shift as countries have developed economically, with poisonings moving away from hydrocarbons and plant products and toward medications and household chemical products.

\section{DISCUSSION}

The age of children who are seen for poisoning is relatively consistent from
TABLE 1. Substances ingested accidentally by children less than 13 years old in Antigua and Barbuda, 1989 to 1999

\begin{tabular}{|c|c|}
\hline $\begin{array}{l}\text { Category/Specific } \\
\text { ingested substance }\end{array}$ & $\begin{array}{l}\text { No. of } \\
\text { patients }\end{array}$ \\
\hline \multicolumn{2}{|l|}{ Chemical } \\
\hline Bleach (“Clorox”) & 50 \\
\hline Lysol (brand of cleanser) & 2 \\
\hline Dettol (brand of cleanser) & 1 \\
\hline Clebar (brand of cleanser) & 1 \\
\hline Rat poison & 27 \\
\hline Caustic & 6 \\
\hline Pesticide & 3 \\
\hline \multicolumn{2}{|l|}{ Medications } \\
\hline Unknown tablet & 18 \\
\hline Salves & 6 \\
\hline Oral contraceptives & 5 \\
\hline Acetaminophen & 4 \\
\hline Potassium supplements & 4 \\
\hline Antiepileptic & 4 \\
\hline Antipsychotic & 4 \\
\hline Aspirin & 3 \\
\hline Benzodiazepine & 3 \\
\hline Antihistamine & 2 \\
\hline Beta-blocker & 2 \\
\hline Albuterol & 2 \\
\hline Decongestant & 1 \\
\hline Pilocarpine & 1 \\
\hline Methyldopa & 1 \\
\hline Enalapril & 1 \\
\hline Hydralazine & 1 \\
\hline Carbimazole & 1 \\
\hline Diphenoxylate & 1 \\
\hline Laxative & 1 \\
\hline Vitamins & 1 \\
\hline \multicolumn{2}{|l|}{ Hydrocarbons } \\
\hline Kerosene & 39 \\
\hline Diesel fuel & 6 \\
\hline Furniture polish & 4 \\
\hline Gasoline & 3 \\
\hline Paint thinner & 3 \\
\hline Engine oil & 2 \\
\hline Brake fluid & 1 \\
\hline Acrylic & 1 \\
\hline Nail polish remover & 1 \\
\hline Pine oil & 1 \\
\hline \multicolumn{2}{|l|}{ Plants } \\
\hline \multicolumn{2}{|l|}{ Manchineel } \\
\hline (Hippomane mancinella) & 5 \\
\hline Walnut (Juglan spp.) seed & 1 \\
\hline Flamboyant (Poinciana spp.) & \\
\hline seed & 1 \\
\hline \multicolumn{2}{|l|}{ Others } \\
\hline Mercury (type not clarified) & 3 \\
\hline Hydrogen peroxide & 2 \\
\hline Glue & 1 \\
\hline Plant food & 1 \\
\hline Perfume & 1 \\
\hline Alcohol & 1 \\
\hline \multicolumn{2}{|l|}{ Disiclin } \\
\hline (brand of disinfectant) & 1 \\
\hline Unknown & 21 \\
\hline
\end{tabular}


TABLE 2. A comparison of gross domestic product (GDP) and of types of childhood poisonings (\%) in countries of the English-speaking Caribbean and the United States of America from 1977 to $1999^{a}$

\begin{tabular}{|c|c|c|c|c|c|}
\hline & $\begin{array}{c}\text { Guyana (1992) } \\
\quad(n=109)\end{array}$ & $\begin{array}{c}\text { Jamaica (1977) } \\
\quad(n=281)\end{array}$ & $\begin{array}{l}\text { Barbados (1978) } \\
\quad(n=491)\end{array}$ & $\begin{array}{c}\text { Antigua and } \\
\text { Barbuda (1994) } \\
(n=255)\end{array}$ & $\begin{array}{l}\text { United States of } \\
\text { America }(1990) \\
(n=1000000)\end{array}$ \\
\hline GDP per capita (US\$) & 995 & 2079 & 3700 & 5377 & 18448 \\
\hline \multicolumn{6}{|l|}{ Type of ingestion: } \\
\hline Hydrocarbon & 61 & 33 & 28 & 24 & 3 \\
\hline Chemical & 16 & 24 & 13 & 35 & 26 \\
\hline Medications & 21 & 18 & 26 & 26 & 45 \\
\hline Plant & $\ldots b$ & $22^{c}$ & 4 & 3 & 9 \\
\hline Otherd & 2 & 3 & 29 & 12 & 17 \\
\hline
\end{tabular}

a For the countries other than Antigua and Barbuda, the information sources are: Guyana (3), Jamaica (2), Barbados (6), and the United States (5). The GDP figures are standardized in 1978 United States dollars; the year indicated for each country is matched to the year of the data from each of the respective reports $(2,3,5,6)$. b The ellipsis points (...) indicate that the information was not available.

c In Jamaica $50 \%$ of the plant poisonings were ackee (Blighia sapida) fruit.

d The "other" category covers items that were not included in the reports from all of the countries, such as food poisoning, fish poisoning (ciguatera), foreign-body ingestion, and ingestions of illicit drugs.

country to country and over time. In a report from poison control centers in the United States, 1-year-old children were the ones most often involved in accidental poisoning, accounting for $28 \%$ of the poisonings in children less than 12 years old (7). They were followed by 2 -year-old children $(27 \%)$ and 3-year-old children (12\%); infants made up $11 \%$. In Guyana, 1-year-old children accounted for $42 \%$, followed by 2 -year-old children $(28 \%)$ and 3 year-old children (14\%) (3). In Barbados, 1-year-old children were $41 \%$, 2 year-old children $25 \%$, and 3-year-old children 12\% (6). In Antigua, 1-yearold children accounted for $45 \%$ of poisonings, with 2-year-old children $(27 \%)$ and 3-year-old children $(10 \%)$ following, and infants accounting for $5 \%$. Only $20 \%$ of reported ingestions in the United States resulted in symptoms (5). A comparable number is not available for the Caribbean as only poisonings presenting at the hospital are included.

By comparing data over several decades and from countries with different levels of economic development, it is possible to discern a change in the spectrum of substances ingested. Antigua and Barbuda has moved from an agricultural economy to a serviceoriented economy, and the substances ingested have come to resemble more those in the United States and less those of its Caribbean neighbors.
Specifically, hydrocarbons such as kerosene become less common due to reliable electrical service and a smaller rural population, and processed foods may replace plant products, making ingestion of hydrocarbons and of plant products less likely. Economic improvements allow for a new variety of household products and medications that can attract children, making poisoning with these products more likely. This is part of a general trend in the Americas, with accidents of various types, including poisoning, assuming a greater importance as a cause of mortality in the wealthier countries, versus the nutritional, gastrointestinal, and respiratory causes of death seen in poorer countries in children 1 to 5 years old (7).

Fatalities associated with ingestions occurred in $2 \%$ of Jamaican children (5 ackee (Blighia sapida) fruit, 1 barbiturate) (2). In Antigua and Barbuda, there was only one fatality, from kerosene, in the 255 admissions (0.4\%). Approximately 20000 children between the age of 0 and 13 years were living in Antigua during each of the years reviewed, giving an incidence of 26 poisonings per year, or 1.3 per 1000 children.

Boys account for $55 \%$ of poisonings in the United States, similar to the 57\% seen in both Barbados (6) and Antigua. This difference is not seen in older patients in the United States, where poi- sonings, often intentional, occur with the same frequency among men and women (8). Disability relating to ingestion is 20 times more common than fatality in the United States (9). However, in this series of patients in Antigua, no disabilities were encountered. The ingestions most likely to be fatal in the United States were iron tablets, antidepressant medications, and hydrocarbons (8). The one death in Antigua and Barbuda was due to hydrocarbon ingestion.

Prevention is much more attractive than treatment. Counseling for injury prevention by primary health care providers increases parental awareness and results in modest changes in behavior, such as having syrup of ipecac available and using latches on cabinets $(10,11)$. Treatment remains primarily supportive except when specific antidotes are available (12). In Antigua, emergency assessment and management include induced emesis or gastric lavage, use of activated charcoal, airway protection, and ventilatory support, if needed. Induced emesis or gastric lavage is useful in most poisonings, except caustic ingestions (esophageal burn risk) and hydrocarbon ingestions (aspiration risk). Activated charcoal is helpful in most cases (12). An excellent review of the management of ingestion of toxic substances by children was published recently (13). 
Poison control centers in the United States have provided a resource for parents and the medical community (8). The centers use toll-free telephone lines and facsimile service to provide information to both individuals and hospitals. The centers also record data on the number and type of ingestions that occur (8).

One of the limitations of this study is the lack of uniformity in data collection and the small numbers of poisonings reviewed in the various coun- tries. In spite of this limitation, our results suggest that accidental poisoning in children remains a significant clinical problem. The age groups most at risk (1 to 3 years old) are relatively constant. There is a suggestion that improving economic conditions may result in a shift away from hydrocarbon and plant ingestions toward ingestions of a greater variety of household products and medications. Given these trends, establishing a poison control center in the English- speaking Caribbean might prove helpful, by providing information to both parents and health care providers, by forming a registry for ingestions, and by tracking incidence and outcome figures.

Acknowledgements. We would like to thank the doctors, nurses, and support staff in the Casualty Department at Holberton Hospital, St John's, Antigua, for their diligence and expertise.

\section{REFERENCES}

1. Wolff AD. Poisoning in children and adolescents. Pediatrics in Rev 1993;14:411-422.

2. Lawrence AWW. Cases of poisoning presenting in the Casualty Department of the Cornwall Regional Hospital, Jamaica. West Indian Med J 1977;26:211-215.

3. Dookhan DA. Poisoning in children at the Georgetown Hospital, Guyana: a two-year review. West Indian Med J 1996;45(suppl 2):33.

4. Williams BC, Miller CA. Preventive health care for young children. Findings from a $10-$ country study and directions for United States policy. Pediatrics 1992:89(Suppl):983-998.

5. Nolan R. Poisoning. In: Hoekelman RA, ed. Primary pediatric care. St. Louis, Missouri, United States of America: Mosby; 1997. Pp. 1738-1750.
6. St. John MA, Talma TE. A 5 year review of poisoning in children in Barbados. West Indian Med J 1982;31:121-125.

7. Pan American Health Organization. Health conditions in the Americas, 1990 ed. Washington, D.C.: PAHO; 1990.

8. Litovitz TL, Klein-Schwartz W, Dyer KS Shannon M, Lee S, Powers M. 1997 annual report of the American Association of Poison Control Centers Toxic Exposures Surveillance System. Amer J Emerg Med 1998;16: 443-497.

9. Litovitz T, Manoguerra A. Comparison of pediatric poisoning hazards: an analysis of 3.8 million exposure incidents. A report from the American Association of Poison Control Centers. Pediatrics 1992;89:999-1006.
10. Bass JL, Christoffel KK, Widome M, Boyle W, Scheidt P, Stanwick R, et al. Childhood injury prevention counseling in primary care settings: a critical review of the literature. Pediatrics 1993;92:544-550.

11. Steele P, Spyker DA. Poisonings. Pediatr Clin North Am 1985;32:77-86.

12. Mandl KD, Lovejoy FH. Common poisonings. Pediatrics in Rev 1994;15:151-156.

13. Shannon M. Ingestion of toxic substances by children. N Engl J Med 2000;342(3):186-191.

Manuscript received 28 December 2001. Revised manuscript accepted for publication 4 September 2002.
RESUMEN

Intoxicaciones infantiles accidentales en el Caribe
Objetivos. Investigar las intoxicaciones accidentales de niños en Antigua y Barbuda desde el punto de vista de la incidencia, tipos de sustancias implicadas, edad de los niños y desenlaces clínicos. Los resultados obtenidos en este país se compararon con los de otros estudios realizados en diferentes países caribeños de habla inglesa y en los Estados Unidos de América (EE. UU.).

Métodos. Se realizó una revisión retrospectiva de las historias clínicas de todos los pacientes de menos de 13 años de edad ingresados entre marzo de 1989 y marzo de 1999 en la planta de pediatría del Hospital Holberton de Antigua por intoxicación accidental. Los datos obtenidos se compararon con los comunicados en estudios anteriores realizados en Barbados, Guyana, Jamaica y EE. UU.

Resultados. Durante este período de 10 años, hubo en Antigua y Barbuda 255 ingresos de niños de menos de 13 años por intoxicación accidental (media de 26 ingresos por año). En una población de aproximadamente 20000 niños menores de 13 años, esto representa una proporción de 1,3 por 1 000. De estos 255 casos, 115 (45\%) ocurrieron en niños de 1 año, 69 (27\%) en niños de 2 años y 26 (10\%) en niños de 3 años. Esta distribución por edades fue similar a la observada en los demás países. Al comparar los tipos de intoxicación en todos los países estudiados, se verificó que las sustancias implicadas cambiaban a medida que aumentaba el nivel económico: disminuían los hidrocarburos y las plantas y aumentaban los medicamentos y los productos químicos. Conclusiones. A medida que aumenta el nivel económico, también lo hace la complejidad de las sustancias implicadas. Esta tendencia debería llevar al establecimiento de un centro de control de intoxicaciones en los países caribeños de habla inglesa. 